Yüzüncü Y1l Üniversitesi
Tarim Bilimleri Dergisi

Araştırma Makalesi (Research Article)

Nitrogen Fertilization Affects Growth, Yield, Nitrate and Mineral Content of Garden Cress (Lepidium sativum L.)

\author{
Ayşegül İNNE ${ }^{1}$, Raziye KUL ${ }^{2}$, Melek EKINCI ${ }^{3}$, Metin TURAN ${ }^{4}$, Ertan YILDIRIM $^{5 *}$ \\ 1,2,3,5 Atatürk University, Faculty of Agriculture, Department of Horticulture, Erzurum-Turkey \\ ${ }^{4}$ Yeditepe University, Engineering Faculty, Department of Genetics and Bioengineering, Istanbul, Turkey \\ ${ }^{1}$ https://orcid.org/0000-0003-1382-6189 2https://orcid.org/ 0000-0002-5836-6473 3https://orcid.org/0000-0002-7604-3803 \\ ${ }^{4}$ https://orcid.org/0000-0002-4849-7680 5https://orcid.org/ 0000-0003-3369-0645 \\ *Sorumlu yazar e-posta: ertanyil@atauni.edu.tr
}

\begin{abstract}
Article Info
Received: 10.11 .2020

Accepted: 09.12.2020

Online Published 30.03.2021

DOI: 10.29133/yyutbd.823959

Keywords

Garden cress,

Growth,

Nitrogen,

Quality,

Yield.

Abstract: Garden cress is rich in carotenoids, vitamin C, fiber, flavonoids, selenium, s-methyl cysteine, sulfoxide and glucosinolates. Nitrogen deficiency is a limiting factor for plant growth. The study was conducted in Atatürk University, in Erzurum under field conditions in 2013 and 2014. The aim of the present study was to evaluate effects of the different ratios of nitrogen on growth, yield and some quality properties of garden cress (cv. Dadaş). Treatments consisted of Nmin (mineral nitrogen in the soil layer 0-30 cm at planting; i.e. no basal nitrogen fertilization) (Control), 50, 100 and $150 \mathrm{~kg} \mathrm{~N}^{-}$ ${ }^{1}$ doses as ammonium nitrate. The effect of different nitrogen doses on the plant height and yield in the cress was statistically significant. The highest plant height and yield was observed in $100 \mathrm{~kg} \mathrm{~N} \mathrm{ha}^{-1}$. Generally, $\mathrm{NO}_{3}$ and the other elements in garden cress increased with increasing nitrogen doses. In conclude $82.17 \mathrm{~kg} \mathrm{~N} \mathrm{ha}^{-1}$ can be suggested for higher yield and quality for Dadaş garden cress variety in sand soil conditions according to the regression analysis.
\end{abstract}

\title{
Azot Gübrelemesinin Terede (Lepidium sativum L.) Büyüme, Verim, Nitrat ve Mineral İçeriğine Etkileri
}

\section{Makale Bilgileri}

Geliş: 10.11 .2020

Kabul: 09.12.2020

Online Yayınlanma 30.03.2021

DOI: 10.29133/yyutbd.823959

\section{Anahtar kelimeler}

Tere,

Bitki gelişimi,

Azot,

Kalite,

Verim.
Öz: Tere, karotenoidler, C vitamini, lif, flavonoidler, selenyum, s-metil sistein, sülfoksit ve glukozinolatlar bakımından zengindir. Azot eksikliği, bitki büyümesi için sınırlayıcı bir faktördür. Bu çalışma 2013 ve 2014 yıllarında Erzurum Atatürk Üniversitesi'nde tarla koşullarında yürütülmüşsür. Çalışmanın amacı, farklı azot oranlarının terede (Dadaş çeşidi) bitki gelişimi, verim ve bazı kalite özellikleri üzerindeki etkilerini değerlendirmektir. Azot uygulamaları, Nmin (ekim öncesi 0-30 cm toprak tabakasındaki mineral azot dikkate alınarak; bazal azot gübrelemesi yok) (Kontrol), $50 \mathrm{~kg} \mathrm{~N} \mathrm{ha}^{-1}, 100 \mathrm{~kg} \mathrm{~N} \mathrm{ha}^{-1}$ ve $150 \mathrm{~kg} \mathrm{~N}$ ha $^{-1}$ dozlarında amonyum nitrat olarak uygulanmıştır. Farklı azot dozlarının terede bitki boyu ve verimi üzerine etkisi istatistiksel olarak önemli bulunmuştur. En yüksek bitki boyu ve verimi $100 \mathrm{~kg} \mathrm{~N}^{-1}$ dozu verilen uygulamada tespit edilmiştir. Artan azot dozları ile genellikle tere içerisindeki $\mathrm{NO}_{3}$ ve diğer elementler artmıştır. Yapılan regresyon analizi sonucunda kumlu topraklarda $82.17 \mathrm{~kg} \mathrm{ha}{ }^{-1}$ azot uygulamalarının Dadaş bahçe teresinde uygulanalabilirliği ortaya konmuştur. 


\section{Introduction}

Garden cress belongs to the Brassicaceae family. The plant, native to Asia and North Africa, is a one-year herbaceous plant. It is used as an appetizer in the form of a salad or garnish vegetable due to its pleasant smell and light spicy structure. Garden cress has been used in the treatment of liver diseases and infections in addition to its use as an immune system enhancer, diuretic (Nadkarni, 1954) and antibacterial (Amin, 2005).

Fertilizer is one of the most important inputs in agricultural production. When it is not applied adequately, it causes significant losses in efficiency and quality, whereas in case of excessive application, it causes pollution of water sources, especially with the washing of nitrogen fertilizers, and the production of greenhouse gases with the emission of nitrogen oxides $\left(\mathrm{NO}, \mathrm{N}_{2} \mathrm{O}\right.$ and $\mathrm{NO}_{2}$ ) (Güler, 2004).

Nitrogen is an important nutrient element in plant cells found in many structural compounds such as chlorophyll and amino acids. Nitrogen deficiency is one of the most important factors in plant growth and development (Tuncay et al., 2011). In addition, if nitrogenous fertilizers are used excessively, the amount of nitrate in the leaf reaches a level that threatens human health, especially in leaf-edible vegetables (Roorda van Eysinga, 1984). The use of unbalanced nitrogen fertilizers causes nitrogen accumulation within the plant and nitrate accumulation if nitrogen is taken in the form of nitrate. Nitrate concentrations can reach high levels in some leafy vegetables such as lettuce and spinach. Nitrate can turn into harmful substances that can cause cancer in humans and animals (Ziarati et al., 2018).

Soil and climatic conditions have an important effect on the nitrogen content of plants. Plants grown in soils rich in absorbable nitrogen contain more nitrate than those grown in soils poor in nitrogen. As a result of the research conducted on the effects of different soils on the nitrate levels of vegetables, it is reported that the amount of nitrate in lettuce, carrot and white cabbage grown in sandy soil with less organic matter is found to be less than those grown in other soils (Geyer, 1978). The nitrate content of vegetables also varies according to species and varieties. In addition to varieties, maturity and leaf types of plants during the harvest period also affect nitrate content (Corre and Breimer, 1979). When producing leafy vegetables, one important aspect is the final plant nitrate content, with its indirect negative effects on human health. Garden cress can be considered as a species of high nitrate accumulating (Cavarianni et al., 2008). Since the vegetation period of leafy vegetables is short, they require high amounts of nutrients, especially nitrogen, in their growth period, making fertilization inevitable. Excessive nitrogen uptake in plant nutrients or inhibition of nitrogen conversion to protein causes nitrogen accumulation in the plant (Maynard et al., 1976).

Garden cress is classified into 2 types according to their leaf shapes, namely flat and segmented leafed cress. The cress grown in our country is mostly in the flat leaf group. On the other hand, in eastern regions of Turkey, garden cress with leaves like parsley is mostly consumed (Yanmaz et al., 2010). As a result of the studies we conducted in Ankara and Erzurum conditions, it was determined that parsley-leaved garden cress was different from the existing cress varieties and it was registered with the name Dadaş. The aim of the present study was to evaluate effects of the different ratios of nitrogen on growth, yield and some quality properties of garden cress (Dadaş cultivar).

\section{Materials and Methods}

The study was carried out in the experimental fields of Atatürk University, Erzurum, Turkey (3991' N; 4136'E; $1900 \mathrm{~m}$ above sea level). Climatic conditions during the experiment are given in Figures $1 \mathrm{a}$ and $\mathrm{b}$. The average temperature ranged between $19.7^{\circ} \mathrm{C}$ (July) and $7.0^{\circ} \mathrm{C}$ (October) in 2013, $21.2^{\circ} \mathrm{C}$ (July) and $8.8^{\circ} \mathrm{C}$ (October) in 2014. Total rainfall was $15.2 \mathrm{~mm}$ in July and $32.7 \mathrm{~mm}$ in October in 2013, and $34.9 \mathrm{~mm}$ in July and $43.4 \mathrm{~mm}$ in October in 2014. Soil properties of the experimental area are given in Table 1 . Manure $\left(30 \mathrm{t} \mathrm{ha}^{-1}\right)$ was applied to plots. Treatments consisted of Nmin (mineral nitrogen in the soil layer $0-30 \mathrm{~cm}$ at planting; i.e. no basal nitrogen fertilization) (Control), $50 \mathrm{~kg} \mathrm{~N} \mathrm{ha}^{-1}, 100 \mathrm{~kg} \mathrm{~N} \mathrm{ha}^{-1}$ and $150 \mathrm{~kg} \mathrm{~N} \mathrm{ha}^{-1}$ as Ammonium Nitrate. A basal dressing of $100 \mathrm{~kg} \mathrm{P} \mathrm{ha}^{-1}$ as triple superphosphate was applied before planting. Garden cress (L. sativum L.) cv. Dadaş was used as plant material. This cultivar "Dadaş" was parsley-leaved garden cress. 
Garden cress (L. sativum L.) seeds $\left(2 \mathrm{~g} \mathrm{~m}^{-2}\right)$ were sown to $2 \mathrm{~m}^{2}$ plots with a $10 \mathrm{~cm}$ space between rows in 22.08.2013 and 19.08.2014. Irrigation was done when needed. Weeding was done by hand. Garden cress plants were harvested by cutting when they have 7-10 leaf in 30.09.2013 and 28.09.2014. At harvesting, plant height, plant fresh weights (FW) and plant dry weights (DW) were calculated. Leaf $\mathrm{NO}_{3}$ content was measured using ion chromatography (Dionex® DX 500; Dionex Corp., Milan, Italy) on a sample of $20 \mathrm{~g}$.

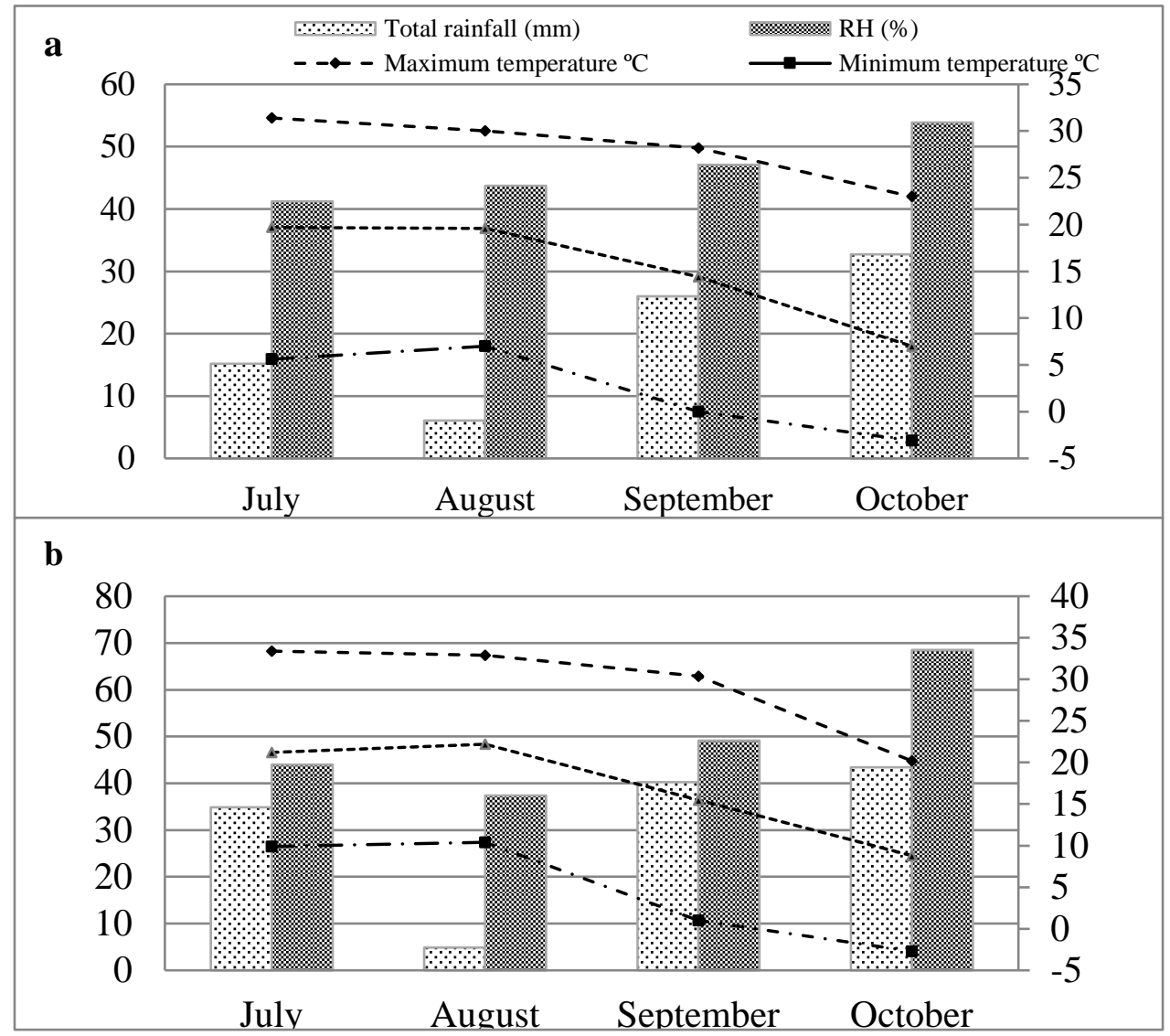

Figure 1. Some meteorological parameters of experimental area in 2013 (a) and 2014 (b).

Table 1. Physical and chemical characteristics of the soil before the experiment (mean \pm standard deviation, $\mathrm{n}=10$ )

\begin{tabular}{lll}
\hline Soil Properties & Units & Means \\
\hline $\mathrm{N}$ & $\left(\mathrm{mg} \mathrm{kg}^{-1}\right)$ & $8.16 \pm 0.75$ \\
$\mathrm{P}$ & $\left({\left.\mathrm{me} 100 \mathrm{~g}^{-1}\right)}^{-1}\right)$ & $12.36 \pm 1.04$ \\
$\mathrm{~K}$ & $\left({\left.\mathrm{me} 100 \mathrm{~g}^{-1}\right)}^{-1}\right)$ & $2.34 \pm 0.16$ \\
$\mathrm{Ca}$ & $\left({\mathrm{me} 100 \mathrm{~g}^{-1}}^{-}\right.$ & $16.75 \pm 2.13$ \\
$\mathrm{Mg}$ & $\left(\mathrm{m} \mathrm{kg}^{-1}\right)$ & $1.44 \pm 0.04$ \\
$\mathrm{Na}$ & $\left(\mathrm{mg} \mathrm{kg}^{-1}\right)$ & $0.35 \pm 0.03$ \\
$\mathrm{Fe}$ & $\left(\mathrm{mg} \mathrm{kg}^{-1}\right)$ & $4.54 \pm 0.24$ \\
$\mathrm{Cu}$ & $\left(\mathrm{mg} \mathrm{kg}^{-1}\right)$ & $5.44 \pm 0.74$ \\
$\mathrm{Mn}$ & $\left(\mathrm{mg} \mathrm{kg}^{-1}\right)$ & $6.45 \pm 0.95$ \\
Zn & $\left(\mathrm{mg} \mathrm{kg}^{-1}\right)$ & $3.65 \pm 0.15$ \\
B & $\left(\mathrm{mg} \mathrm{kg}^{-1}\right)$ & $0.24 \pm 0.01$ \\
Organic matter & $(\%)$ & $0.76 \pm 0.09$ \\
Sand & $(\%)$ & $38.4 \pm 2.48$ \\
Silt & $(\%)$ & $34.1 \pm 3.04$ \\
Clay & $(\%)$ & $27.5 \pm 1.19$ \\
\hline
\end{tabular}


Ascorbic acid (Vitamin C) was determined with a Merck reflectometer set (Merck RQflex). To determine the mineral concentrations of garden cress leaves was used an inductively coupled plasma spectrophotometer (Optima 2100 DV; Perkin-Elmer, Shelton, CT) (Bremner, 1996). The experimental design was a randomized complete block design with three replications. Data were subjected to the analysis of variance (ANOVA) to compare the effects of treatments. When significant differences occurred, the differences of means were determined using Duncan. Regression analysis was made on the effect of nitrogen applications on yield.

\section{Results}

In the study, it was determined that the effect of different nitrogen doses on the plant height and yield in the garden cress was statistically significant $(\mathrm{p}<0.001)$ in both years. However, nitrogen treatments did not affect significantly branch number of garden cress (Table 2). The highest plant height and yield were observed in $100 \mathrm{~kg} \mathrm{~N} \mathrm{ha}^{-1}$ while the lowest were determined in the control. Similarly, the FW and DW were the highest in $100 \mathrm{~kg} \mathrm{~N} \mathrm{ha}^{-1}$ treatment. Further nitrogen increase caused reduced FW and DW of garden cress. The lowest FW and DW occurred in the control. The results of the study increasing $\mathrm{N}$ doses reduced Vitamin $\mathrm{C}$. The lowest Vitamin $\mathrm{C}$ content was determined in $100 \mathrm{~kg} \mathrm{~N} \mathrm{ha}^{-1}$ while the highest was in the control (Table 3).

Table 2. Plant height, branch number and yield response of garden cress to $\mathrm{N}$ fertilization

\begin{tabular}{llllllllll}
\hline $\mathrm{N}$ & \multicolumn{3}{c}{ Plant height $(\mathrm{cm})$} & \multicolumn{3}{c}{ Branches number/plant } & \multicolumn{3}{l}{ Yield g/m ${ }^{2}$} \\
\cline { 2 - 10 }$\left(\mathrm{kg} \mathrm{ha}^{-1}\right)$ & $1^{\text {st }}$ year & $2^{\text {nd }}$ year & Mean & $1^{\text {st }}$ year & $2^{\text {nd }}$ year & Mean & $1^{\text {st }}$ year & $2^{\text {nd }}$ year & Mean \\
\hline 0 & $23.71 \mathrm{~b}$ & $23.27 \mathrm{~b}$ & $23.49 \mathrm{~B}$ & 11.60 & 8.43 & 10.02 & $2315.95 \mathrm{c}$ & $4730.00 \mathrm{c}$ & $3522.98 \mathrm{D}$ \\
50 & $25.43 \mathrm{a}$ & $26.20 \mathrm{a}$ & $25.81 \mathrm{~A}$ & 10.83 & 8.30 & 9.57 & $2995.07 \mathrm{ab}$ & $5240.00 \mathrm{~b}$ & $4117.53 \mathrm{~B}$ \\
100 & $26.93 \mathrm{a}$ & $26.34 \mathrm{a}$ & $26.63 \mathrm{~A}$ & 10.70 & 8.23 & 9.47 & $3193.87 \mathrm{a}$ & $5530.00 \mathrm{a}$ & $4361.93 \mathrm{~A}$ \\
150 & $26.70 \mathrm{a}$ & $26.53 \mathrm{a}$ & $26.62 \mathrm{~A}$ & 10.90 & 8.13 & 9.52 & $2846.55 \mathrm{~b}$ & $4620.00 \mathrm{c}$ & $3733.28 \mathrm{C}$ \\
\hline $\mathrm{P}$ & $<0.01$ & $<0.001$ & $<0.001$ & $>0.05$ & $>0.05$ & $>0.05$ & $<0.001$ & $<0.001$ & $<0.001$ \\
\hline
\end{tabular}

The difference between the means indicated with the same letter is not statistically significant.

Table 3. Fresh weight (FW), dry weight (DW) and Vitamin C content response of garden cress to N fertilization

\begin{tabular}{llllllllll}
\hline $\mathrm{N}$ & \multicolumn{3}{c}{ FW $(\mathrm{g})$} & \multicolumn{3}{c}{ DW $(\mathrm{g})$} & \multicolumn{3}{c}{ Vitamin C } \\
\cline { 2 - 10 }$\left(\mathrm{kg} \mathrm{ha}^{-1}\right)$ & $1^{\text {st }}$ year & $2^{\text {nd }}$ year & Mean & $1^{\text {st }}$ year & $2^{\text {nd }}$ year & Mean & $1^{\text {st }}$ year & $2^{\text {nd }}$ year & Mean \\
\hline 0 & $66.17 \mathrm{c}$ & $157.67 \mathrm{c}$ & $111.92 \mathrm{D}$ & $7.64 \mathrm{~b}$ & $10.71 \mathrm{c}$ & $9.18 \mathrm{C}$ & $135.33 \mathrm{a}$ & $146.67 \mathrm{a}$ & $141.00 \mathrm{~A}$ \\
50 & $85.57 \mathrm{ab}$ & $174.67 \mathrm{~b}$ & $130.12 \mathrm{~B}$ & $8.79 \mathrm{~b}$ & $12.58 \mathrm{~b}$ & $10.69 \mathrm{~B}$ & $137.33 \mathrm{a}$ & $138.00 \mathrm{ab}$ & $137.67 \mathrm{~A}$ \\
100 & $91.25 \mathrm{a}$ & $184.33 \mathrm{a}$ & $137.79 \mathrm{~A}$ & $10.71 \mathrm{a}$ & $11.58 \mathrm{~b}$ & $11.15 \mathrm{~A}$ & $115.33 \mathrm{c}$ & $130.00 \mathrm{~b}$ & $122.67 \mathrm{C}$ \\
150 & $81.33 \mathrm{~b}$ & $154.00 \mathrm{c}$ & $117.67 \mathrm{C}$ & $8.22 \mathrm{~b}$ & $11.95 \mathrm{a}$ & $10.09 \mathrm{~B}$ & $125.00 \mathrm{~b}$ & $136.00 \mathrm{ab}$ & $130.50 \mathrm{~B}$ \\
\hline $\mathrm{P}$ & $<0.001$ & $<0.001$ & $<0.001$ & $<0.01$ & $<0.01$ & $>0.05$ & $<0.001$ & $<0.05$ & $<0.001$ \\
\hline
\end{tabular}

The difference between the means indicated with the same letter is not statistically significant.

The nitrate and plant nutrient content of garden cress grown under different nitrogen doses are given in Tables 4, 5, 6 and 7. Nitrogen treatments affected significantly $\mathrm{NO}_{3}$ and the other elements except for $\mathrm{B}$ content of garden cress. Generally, $\mathrm{NO}_{3}$ and the other elements in garden cress increased with increasing nitrogen doses. The highest values of $\mathrm{NO}_{3}, \mathrm{~N}, \mathrm{P}, \mathrm{K}, \mathrm{Ca}, \mathrm{Mg}, \mathrm{Fe}$ and $\mathrm{Cu}$ were obtained from $150 \mathrm{~kg} \mathrm{~N} \mathrm{ha}^{-1}$ treatment while the lowest ones generally were in the control. $\mathrm{Na}, \mathrm{Mn}$ and $\mathrm{Zn}$ content changed depending on nitrogen doses. 
Table 4. Nitrate $\left(\mathrm{NO}_{3}\right)$, nitrogen $(\mathrm{N})$ and phosphorus $(\mathrm{P})$ content response of garden cress to $\mathrm{N}$ fertilization

\begin{tabular}{llllllllll}
\hline $\mathrm{N}$ & \multicolumn{3}{c}{$\mathrm{NO}_{3}\left(\mathrm{mg} \mathrm{kg}^{-1}\right)$} & \multicolumn{3}{c}{$\mathrm{N}(\%)$} & \multicolumn{3}{c}{$\mathrm{P}\left(\mathrm{mg} \mathrm{kg}^{-1}\right)$} \\
\cline { 2 - 10 }$\left(\mathrm{kg} \mathrm{ha}^{-1}\right)$ & $1^{\text {st }}$ year & $2^{\text {nd }}$ year & Mean & $1^{\text {st }}$ year & $2^{\text {nd }}$ year & Mean & $1^{\text {st }}$ year & $2^{\text {nd }}$ year & Mean \\
\hline 0 & $385.72 \mathrm{~d}$ & $424.97 \mathrm{c}$ & $405.35 \mathrm{D}$ & $2.50 \mathrm{~d}$ & $2.63 \mathrm{~d}$ & $2.57 \mathrm{D}$ & $2660.51 \mathrm{~b}$ & $2883.93 \mathrm{~b}$ & $2772.22 \mathrm{C}$ \\
50 & $415.00 \mathrm{c}$ & $453.00 \mathrm{~b}$ & $434.00 \mathrm{C}$ & $2.63 \mathrm{c}$ & $2.85 \mathrm{c}$ & $2.74 \mathrm{C}$ & $2702.65 \mathrm{~b}$ & $3144.42 \mathrm{a}$ & $2923.53 \mathrm{~B}$ \\
100 & $486.07 \mathrm{~b}$ & $461.78 \mathrm{~b}$ & $473.92 \mathrm{~B}$ & $2.89 \mathrm{~b}$ & $2.99 \mathrm{~b}$ & $2.95 \mathrm{~B}$ & $2804.23 \mathrm{~b}$ & $3230.49 \mathrm{a}$ & $3017.36 \mathrm{~B}$ \\
150 & $505.23 \mathrm{a}$ & $508.24 \mathrm{a}$ & $506.74 \mathrm{~A}$ & $3.01 \mathrm{a}$ & $3.18 \mathrm{a}$ & $3.10 \mathrm{~A}$ & $3083.88 \mathrm{a}$ & $3195.06 \mathrm{a}$ & $3139.47 \mathrm{~A}$ \\
\hline $\mathrm{P}$ & $<0.001$ & $<0.001$ & $<0.001$ & $<0.001$ & $<0.001$ & $<0.001$ & $<0.01$ & $<0.001$ & $<0.001$ \\
\hline
\end{tabular}

The difference between the means indicated with the same letter is not statistically significant.

Table 5. Potassium (K), calcium (Ca) and magnesium (Mg) content response of garden cress to $\mathrm{N}$ fertilization

\begin{tabular}{|c|c|c|c|c|c|c|c|c|c|}
\hline \multirow[t]{2}{*}{$\mathrm{N}\left(\mathrm{kg} \mathrm{ha}^{-1}\right)$} & \multicolumn{3}{|c|}{$\left.\mathrm{K}(\mathrm{mg} \mathrm{kg})^{-1}\right)$} & \multicolumn{3}{|c|}{$\mathrm{Ca}\left(\mathrm{mg} \mathrm{kg}^{-1}\right)$} & \multicolumn{3}{|c|}{$\operatorname{Mg}\left(\mathrm{mg} \mathrm{kg}^{-1}\right)$} \\
\hline & $1^{\text {st }}$ year & $2^{\text {nd }}$ year & Mean & $1^{\text {st }}$ year & $2^{\text {nd }}$ year & Mean & $1^{\text {st }}$ year & $2^{\text {nd }}$ year & Mean \\
\hline 0 & $16406.77 b$ & $16003.02 \mathrm{a}$ & $16204.90 \mathrm{~B}$ & 5049.61a & $4281.01 \mathrm{a}$ & $4665.31 \mathrm{AB}$ & $1840.80 \mathrm{c}$ & $1891.65 a$ & 1866.23B \\
\hline 50 & 16673.12b & $16415.20 \mathrm{a}$ & 16544.16 B & 4717.22b & 4369.04a & 4543.13 B & $1971.82 b$ & 1943.79a & $1957.81 \mathrm{~A}$ \\
\hline 100 & $16501.12 b$ & 16831.60a & 16666.36 B & $4782.08 \mathrm{~b}$ & $4507.57 a$ & 4644.83AB & $2017.15 b$ & $1939.57 a$ & 1978.36A \\
\hline 150 & $17918.92 \mathrm{a}$ & $16585.01 \mathrm{a}$ & $17251.97 \mathrm{~A}$ & $5046.17 \mathrm{a}$ & $4403.48 \mathrm{a}$ & $4724.83 \mathrm{~A}$ & $2108.52 a$ & 1851.98a & 1980.25A \\
\hline $\mathrm{P}$ & $<0.01$ & $>0.05$ & $<0.01$ & $<0.05$ & $>0.05$ & $>0.05$ & $<0.001$ & $>0.05$ & $<0.01$ \\
\hline
\end{tabular}

The difference between the means indicated with the same letter is not statistically significant.

Table 6. Sodium (Na), iron ( $\mathrm{Fe}$ ) and copper $(\mathrm{Cu})$ content response of garden cress to $\mathrm{N}$ fertilization

\begin{tabular}{|c|c|c|c|c|c|c|c|c|c|}
\hline \multirow[t]{2}{*}{$\mathrm{N}\left(\mathrm{kg} \mathrm{ha}^{-1}\right)$} & \multicolumn{3}{|c|}{$\mathrm{Na}\left(\mathrm{mg} \mathrm{kg}^{-1}\right)$} & \multicolumn{3}{|c|}{$\mathrm{Fe}\left(\mathrm{mg} \mathrm{kg}^{-1}\right)$} & \multicolumn{3}{|c|}{$\mathrm{Cu}\left(\mathrm{mg} \mathrm{kg}^{-1}\right)$} \\
\hline & $1^{\text {st }}$ year & $2^{\text {nd }}$ year & Mean & $1^{\text {st }}$ year & $2^{\text {nd }}$ year & Mean & $1^{\text {st }}$ year & $2^{\text {nd }}$ year & Mean \\
\hline 0 & $616.45 \mathrm{a}$ & $549.63 \mathrm{a}$ & $563.04 \mathrm{AB}$ & $136.85 \mathrm{~b}$ & $145.15 \mathrm{~b}$ & $140.99 \mathrm{~B}$ & $32.26 \mathrm{ab}$ & $31.10 \mathrm{c}$ & $31.68 \mathrm{~B}$ \\
\hline 50 & 598.72 a & $555.75 \mathrm{a}$ & 577.23 A & $131.88 \mathrm{~d}$ & $154.29 \mathrm{a}$ & $143.08 \mathrm{~B}$ & 34.33 a & $33.28 \mathrm{~b}$ & $33.83 \mathrm{~A}$ \\
\hline 100 & $556.74 \mathrm{a}$ & $544.22 \mathrm{a}$ & $550.48 \mathrm{AB}$ & $141.19 \mathrm{~b}$ & $155.50 \mathrm{a}$ & $148.35 \mathrm{~A}$ & $30.62 \mathrm{~b}$ & 36.27 a & $33.45 \mathrm{~A}$ \\
\hline 150 & $554.51 \mathrm{a}$ & $504.11 \mathrm{a}$ & $529.31 \mathrm{~B}$ & $147.54 \mathrm{a}$ & $154.00 \mathrm{a}$ & $150.77 \mathrm{~A}$ & $33.82 \mathrm{a}$ & $34.57 \mathrm{ab}$ & $34.20 \mathrm{~A}$ \\
\hline $\mathrm{P}$ & $>0.05$ & $>0.05$ & $<0.05$ & $<0.001$ & $<0.05$ & $<0.001$ & $<0.01$ & $<0.01$ & $<0.01$ \\
\hline
\end{tabular}

The difference between the means indicated with the same letter is not statistically significant.

Table 7. Manganese (Mn), zinc (Zn) and boron (B) content response of garden cress to $\mathrm{N}$ fertilization.

\begin{tabular}{|c|c|c|c|c|c|c|c|c|c|}
\hline \multirow[t]{2}{*}{$\mathrm{N}\left(\mathrm{kg} \mathrm{ha}^{-1}\right)$} & \multicolumn{3}{|c|}{$\operatorname{Mn}\left(\mathrm{mg} \mathrm{kg}^{-1}\right)$} & \multicolumn{3}{|c|}{$\mathrm{Zn}\left(\mathrm{mg} \mathrm{kg} \mathrm{kg}^{-1}\right)$} & \multicolumn{3}{|c|}{$\mathrm{B}\left(\mathrm{mg} \mathrm{kg}^{-1}\right)$} \\
\hline & $1^{\text {st }}$ year & $2^{\text {nd }}$ year & Mean & $1^{\text {st }}$ year & $2^{\text {nd }}$ year & Mean & $1^{\text {st }}$ year & $2^{\text {nd }}$ year & Mean \\
\hline 0 & $47.37 \mathrm{c}$ & $40.60 \mathrm{c}$ & $43.98 \mathrm{D}$ & $37.72 \mathrm{a}$ & $41.12 \mathrm{c}$ & $39.42 \mathrm{~B}$ & $26.92 \mathrm{a}$ & $25.76 \mathrm{~b}$ & $26.34 \mathrm{~A}$ \\
\hline 50 & 48.61 bc & $43.36 \mathrm{~b}$ & $45.98 \mathrm{C}$ & $41.25 \mathrm{a}$ & $41.89 \mathrm{bc}$ & $41.57 \mathrm{~A}$ & $26.27 \mathrm{a}$ & $27.54 \mathrm{a}$ & $26.90 \mathrm{~A}$ \\
\hline 100 & 54.07 a & $44.27 \mathrm{~b}$ & $49.17 \mathrm{~A}$ & 37.85 a & 45.45 a & $41.65 \mathrm{~A}$ & $26.91 \mathrm{a}$ & $24.74 b$ & $25.82 \mathrm{~A}$ \\
\hline 150 & $49.03 \mathrm{~b}$ & $46.27 \mathrm{a}$ & $47.65 \mathrm{~B}$ & $38.22 \mathrm{a}$ & $43.91 \mathrm{ab}$ & $41.07 \mathrm{AB}$ & $26.38 \mathrm{a}$ & $25.70 \mathrm{~b}$ & $26.04 \mathrm{~A}$ \\
\hline $\mathrm{P}$ & $<0.001$ & $<0.001$ & $<0.001$ & $>0.05$ & $<0.01$ & $<0.05$ & $>0.05$ & $<0.05$ & $>0.05$ \\
\hline
\end{tabular}

The difference between the means indicated with the same letter is not statistically significant.

According to the regression analysis for an average of 2 years, the highest yield of garden cress was recorded at $82.17 \mathrm{~kg} \mathrm{~N} \mathrm{ha}^{-1}$, while saving approximately $45 \%$ of nitrogen fertilizer yet giving 15\% more yield compared with $150 \mathrm{~kg} \mathrm{~N} \mathrm{ha}^{-1}$ (Figure 2). 


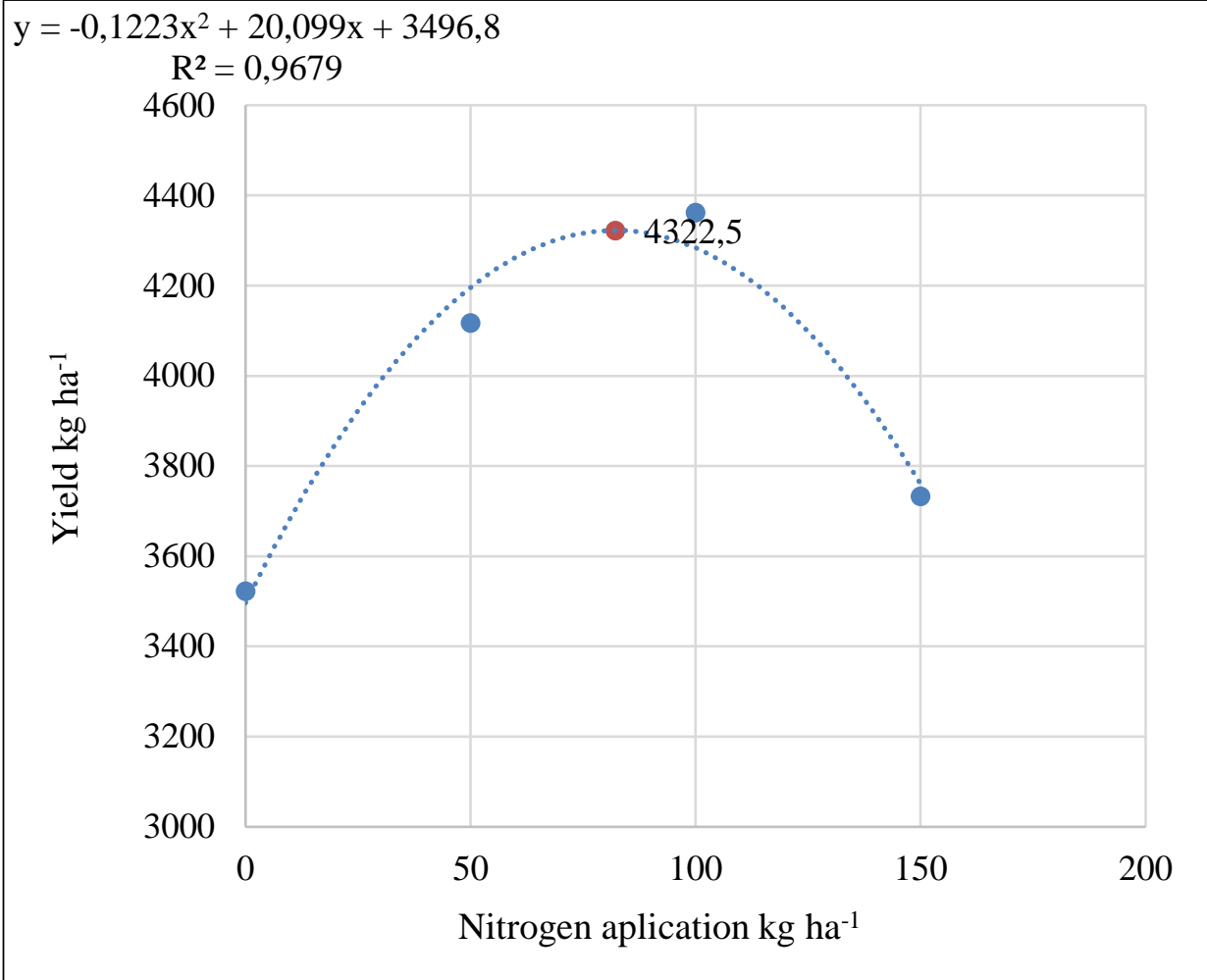

Figure 2. Effects of $\mathrm{N}$ fertilizer applied at different levels on yield of garden cress.

\section{Discussion and Conclusion}

In the study, it was determined that nitrogen fertilization significantly increased plant growth in garden cress. According to the results of the research; it has been observed that all fertilizer applications increase plant growth in garden cress compared to plants under control. In the light of the parameters examined, when nitrogen doses are compared among themselves, $100 \mathrm{~kg} \mathrm{ha}^{-1}$ nitrogen dose was found to be the most effective dose. Many studies pointed out that nitrogen fertilization increases plant growth and yield of several crops (Turan, 2002; Albayrak et al., 2006; Tekeli and Daşgan, 2013).

It is inevitable to use inorganic fertilizers, especially nitrogen fertilization, to increase the vegetative growth of plants. Nitrogen, which forms the main part of protein and nucleic acids, which are the basis of all living forms, is the most used nutrient element in vegetable cultivation, and product amount and quality losses occur in its deficiency (Mengel, 1991). In addition, nitrogen is a structural part of chlorophyll, phospholipids, alkaloids, enzymes, coenzymes, hormones and vitamins (Castellanos et al., 2000). Studies have reported that nitrogen applications significantly affect the yield and quality of lettuce and spinach and generally increase the plant growth and yield in parallel with the increase in nitrogen dose up to a certain level (Topçuoğlu and Yalçin, 1996; Mordoğan et al., 2001). Yadav et al. (2013) planted garden cress in two seasons to examine the effect of planting date, row spacing and nitrogen doses in an experiment they conducted. On the yield of L. sativum L. grown in irrigated loamy sandy soils, 40 and $60 \mathrm{~kg} \mathrm{ha}^{-1}$ nitrogen application was found to be the most effective dose. Boroujerdnia and Ansari (2007) reported in their study that plant growth and yield in lettuce increased up to a certain level in parallel with increasing nitrogen dose. Our study results showed that nitrogen fertilization negatively affected Vitamin $\mathrm{C}$ content of garden cress. A high dose of $\mathrm{N}$ treatments has been reported to decrease vitamin $\mathrm{C}$ content in vegetable crops (Miceli and Miceli, 2014). Previous reports confirm that increasing nitrogen fertilization rates caused reduced vitamin $C$ content in some vegetables (Mozafar, 1993; Lee and Kader, 2000; Yildirim et al., 2007; Yildirim et al., 2020).

According to the macro and micronutrient element analysis results, it was determined that there were important differences between the different nitrogen doses. The highest plant N, P, K, Ca, $\mathrm{Mg}, \mathrm{Fe}$ and $\mathrm{Cu}$ content were determined in $150 \mathrm{~kg} \mathrm{ha}^{-1}$. In parallel with the findings obtained from the 
study, it has been reported that with nitrogen fertilizers applied to the soil in increasing amounts, the $\mathrm{N}$ content of spinach plant increased, but contrary to our findings, other element contents decreased (Topçuoğlu and Yalçin, 1996). In a study conducted to determine the effect of the use of organic and chemical fertilizers on the nutritional status of the plant in peppers, N, P, K, Ca, Mg, Fe and Mn concentrations have been reported to increase significantly with the effect of different fertilizer applications (Özkan et al., 2013). In a study conducted in pots under greenhouse conditions, it was found that four different doses of nitrogen application (0, 200, 400, and $\left.600 \mathrm{mg} \mathrm{N} \mathrm{kg}^{-1}\right)$ increased the nitrogen content in the leaf and root of lettuce, but decreased the phosphorus and potassium content (Petridis et al., 2013).

The results obtained from the study showed that the highest $\mathrm{NO}_{3}$ content in garden cress was determined in the highest application $\left(150 \mathrm{~kg} \mathrm{ha}^{-1}\right)$ of the commercial form of nitrogen fertilizer (Table 2). In parallel with the findings obtained from our study, studies have been conducted showing that the $\mathrm{NO}_{3}$ content in the leaf increases with the increase of the nitrogen dose applied in spinach and lettuce (Smatanova et al., 2004; Liu et al., 2014). In a study conducted under greenhouse conditions, the effect on plant growth and nitrate content in the leaf was investigated in two lettuce varieties grown at two nitrogen levels. At the end of the study, it was determined that high nitrogen dose increased $\mathrm{NO}_{3}$ accumulation in leaves (Balanza et al., 2011). Yağmur et al. (2019) determined that the highest nitrate, nitrite and total nitrogen values of flat leaved garden cress occurred in nitrate fertilizer application.

In case of high $\mathrm{NO}_{3}$ concentration taken through the diet, it can either directly cause the intestinal membranes to break down or it can turn into nitrite and prevent oxygen transport in the blood. In addition, it can transform into nitrosamines in the body and have a carcinogenic effect. This is especially important for vegetables whose leaves are eaten, as nitrate accumulates in the leaves. According to Venter (1978), nitrate value in lettuce leaves varies as 282-3520 mg NO$~ \mathrm{~kg}^{-1}$ fresh weight (ppm) (Ceylan et al., 2001). The maximum nitrate limit in the leaves of lettuce grown in the open field by the European Union has been determined as 3500-4000 ppm (Özgen, 2009). The values obtained in the study were found to be far below the given values.

In order to ensure high efficiency in agricultural production, large amounts of chemical fertilizers are used, which causes human health, environmental and economic problems. Studies have started to intensify in recent years to reduce or eliminate the negative effects of such practices. Garden cress is very sensitive to fertilization, especially nitrogen fertilization, and fertilization is the most important factor affecting yield and quality when other conditions are equal. However, in case of excessive nitrogen use, nitrogen may accumulate in the leaves of the plant as nitrite, which may be harmful to human health. For this reason, $\mathrm{N}$ should not be given to the soil more than enough for the development of the plant (Şalk et al., 2008). Excessive nitrogen applications cause deterioration of the quality of vegetables and some physiological disorders such as tip burn (McCollum, 1992). To conclude 82.17 $\mathrm{N} \mathrm{ha}^{-1}$ can be suggested for higher yield and quality for Dadaş garden cress variety in sand soil conditions according to the regression analysis.

\section{References}

Albayrak, S., \& Çamaş, N. (2006). Yem şalgamı (Brassica rapa L.) çeşitlerinin azotlu gübrelemeye karşı performansları. Ondokuz Mayıs Üniversitesi Ziraat Fakültesi Dergisi, 21(1), 44-48.

Amin, G. H. (2005). Medicinal Plants of Iran, Tehran University Publication, p. 106.

Balanza, V., Martinez, J. A., Conesa, E., Egea-Gilabert, C., Niñirola, D., López-Marín, J., González, A., \& Fernández J.A. (2011). Effect of PGPR application and nitrogen doses on baby leaf lettuce grown in a floating system (abstract only). International Symposium on Advanced Technologies and management Towards Sustainable Greenhouse Ecosystems: Greensys. http://www. actahort.org/books/952/952_86.htm (accessed 15 May 2014).

Boroujerdnia, M., \& Ansari, N.A. (2007). Effect of different levels of nitrogen fertilizer and cultivars on growth, yield and yield components of romaine lettuce (Lactuca sativa L.). Middle Eastern and Russian Journal of Plant Science and Biotechnology, 1, 47-53.

Bremner, J.M. (1996). Nitrogen-total, in: D.L. Sparks (Ed.), Methods of Soil Analysis. Part III. Chemical Methods, 2nd ed. Soil Science Society of America, Madison, WI, USA, 1996, pp. 1085-1122. 
Castellanos, J. Z., Uvalle-Bueno, J. X., \& Aguilar-Santelises, Y. A. (2000). Manual de interpretación de análisis de suelos, aguas agrícolas, plantas ECP. $2^{\mathrm{a}}$ ed. INIFAP, Chapingo, México.

Cavarianni, R. L., Cecílio Filho, A. B., Cazetta, J. O., May, A., \& Corradi, M. M. (2008). Nutrient contents and production of rocket as affected by nitrogen concentrations in the nutritive solution. Scientia Agricola, 65(6), 652-658.

Ceylan, Ş., Mordoğan, N., Yoldaş, F., \& Yağmur, B. (2001). Azotlu gübrelemenin domates bitkisinde verim, azot birikimi ve besin element içeriği üzerine etkisi, Ege Üniversitesi Ziraat Fakültesi Dergisi, 38(2-3), 103-110.

Corre, W. J, \& Breimer, T. (1979). Nitrate and nitrite in vegetables. Wageningen, p. 85.

Geyer, B. (1978). Untersuchungen zur wirkung hoher stickstoffgaben auf den nitratgenalt von freiland gemüse arch. Gartenbau, 26, 1-13.

Güler, S. (2004). Dünya'da ve Türkiye'de Gübre Tüketiminde Yaşanan Gelişmeler. In: Karaman, M.R., \& Brohi, A. R. (eds). Türkiye 3. Ulusal Gübre Kongresi, Tarım- Sanayi-Çevre, 11-13 Ekim 2004, Tokat, 47-54.

Lee, S. K., \& Kader, A. A. (2000). Preharvest and postharvest factors influencing vitamin C content of horticultural crops. Postharvest Biology and Technology, 20(3), 207-220.

Liu, C. W., Sung, Y., Chen, B. C., \& Lai, H. Y. (2014). Effects of nitrogen fertilizers on the growth and nitrate content of lettuce (Lactuca sativa L.). International Journal of Environmental Research and Public Health, 11(4), 4427-4440.

Maynard, D. N., Barker, A. Y., Minotti, P. L., \& Peck, N. H. (1976). Nitrate accumulation in vegetables. Analysis in Agronomy, 28, 71.

Mccollum, J. P. (1992). Vegetable Crops. Danville: Interstate Publishers, Inc.

Mengel, K. (1991). Available nitrogen in soils and its determination by the nmin-method and by electro ultrafiltration (EUF”). Fertilizer Research, 28, 251-262.

Miceli, A., \& Miceli, C. (2014). Effect of nitrogen fertilization on the quality of Swiss chard at harvest and during storage as minimally processed produce. Journal of Food Quality, 37, 125-134.

Mordoğan, N., Ceylan, S., Çakıcı, H., \& Yoldaş, F. (2001). Azotlu gübrelemenin marul bitkisindeki azot birikimine etkisi, Ege Üniversitesi Ziraat Fakültesi Dergisi, 38(1), 85-92.

Mozafar, A. (1993). Nitrogen fertilizers and the amount of vitamins in plants: A review, Journal of Plant Nutrition, 16(12), 2479-2506.

Nadkarni, K. M., \& Nadkarni, A. K. (1954). Lepidium sativum Linn. In: The Indian Medica with Ayurvedic, Unani and Home Remedies, Bombay, India, Popular Prakashan, $3^{\text {rd }}$ edn: 736-737.

Özgen, Ş. (2009). Sebzelerde nitrat birikimi, insan sağlığı açısından önemi ve ihracattaki yeni düzenlemeler. Hasad-Bitkisel Üretim Dergisi, 239, 64-66.

Özkan, C. F., Asri, F. Ö., Demirtaş, E. I., \& Arı, N. (2013). Örtüaltı biber yetiştiriciliğinde organik ve kimyasal gübre uygulamalarının bitkinin beslenme durumu ve bitki gelişimi üzerine etkileri. Toprak Su Dergisi, 2 (2), 96-101.

Petridis, A., Gasparatos, D., Haidouti, C., Paschalidis, C., \& Zamanidis, P. (2013). Effects of nitrogen and boron fertilization on lettuce mineral nutrition in a calcareous soil. Communications in Soil Science and Plant Analysis, 44, 733-740.

Roorda van Eysinga, J. P. N. L. (1984). Nitrate in vegetables under protected cultivation. Acta Horticulturae, 145, 251-256

Smatanova, M., Richter, R., \& Hulisek J. (2004). Spinach and pepper response to nitrogen and sulphur fertilization. Plant, Soil and Environment, 50(7), 303-308.

Şalk, A., Arın, L., Deveci, M., \& Polat, S. (2008). Özel Sebzecilik. Tekirdağ, 485 s.

Tekeli, E., \& Daşgan, H. Y. (2013). Sera biber yetiştiriciliğinde organik azot beslemesinin optimizasyonu. Çukurova Üniversitesi Fen ve Mühendislik Bilimleri Dergisi, (29)2, 49-57.

Topçuoğlu, B., \& Yalçın, S. R. (1996). Azotlu ve fosforlu gübrelemenin 1spanak bitkisinin (Spinaceae oleraceae L.) bazı makro ve mikro besin maddesi içerikleri üzerine etkisi, Tarım Bilimleri Dergisi, 2(2), 39-48.

Tuncay, Ö., Eşiyok, D., Yağmur, B., \& Okur, B. (2011). Yield and quality of garden cress affected by different nitrogen sources and growing period. African Journal of Agricultural Research, 6(3), 608-617. 
Turan, M. (2002). Farklı azotlu gübrelerin erzurum yöresinde yetiştirilen beyaz lahana (Brassica olerecea var. capitate)'nın verim, nitrat birikimi, toprak ve bitkisel özelliklerine etkisi. (PhD), Atatürk Üniversitesi Fen Bilimleri Enstitüsü, Toprak Anabilim Dalı, Erzurum.

Venter, F. (1978). Untersuchungen uberden nitrat gehalt in gemuse. Der Stickstoff, 12, 13-38.

Yadav, L. R., Choudhary, S., Keshwa, G. L. \& Sharma, O. P. (2013). Garden cress (Lepidium sativum) growth, productivity and nutrient uptake under different sowing dates, row spacing and nitrogen levels. Journal article : Indian Journal of Agriculture, 58(1), 114-118.

Yağmur, B., Okur, B., Tuncay, Ö., \& Eşiyok, D. (2019). Farklı ekim zamanı ve azotlu gübre uygulamalarının tere (Lepidium sativum L.) bitkisinin azot fraksiyonlan ve bitki besin maddesi içeriğine etkileri. Yüzüncü Yıl Üniversitesi Tarım Bilimleri Dergisi, 29(3), 388-396.

Yanmaz, R., Yıldırım, E., \& Koyuncu, D. (2010). Ülkemiz için yeni bir tere (Lepidium sativum var. sativum) çeşit adayı: Dadaş. Atatürk Üniversitesi, Ziraat Fakültesi Dergisi, 41(2), 91-95.

Yildirim, E., Güvenç, İ., Turan, M., \& Karataş, A. (2007). Effect of foliar urea application on quality, growth, mineral uptake and yield of broccoli (Brassica oleracea L. var. italica). Plant, Soil and Environment, 53 (3), 120-128.

Yildirim, E., Cil, B., Ekinci, M., Turan, M., Dursun, A., Gunes, A., Kul, R., \& Kitir, N. (2020). Effects of intercropping system and nitrogen fertilization on land equivalent ratio, yield and mineral content of broccoli. Acta Scientiarum Polonorum Hortorum Cultus, 19(3), 101-109.

Ziarati, P., Tamaskani, Z. M., Shirkhan, F., Mostafidi, M., \& Hochwimmer, B. (2018). Potential health risks and concerns of high levels of nitrite and nitrate in food sources. SciFed Pharmaceutics Journal, 1, 1-13. 